Diseminasi: Jurnal Pengabdian kepada Masyarakat

Volume: 1 No: 2 Tahun 2019

E-ISSN: 2655-2221 P-ISSN: 2655-2175

Hal: 46-68

\title{
LIFE SKILLS EDUCATION FOR SCHOOL DROP OUTS IN TAMAN SARI,
} DISTRICT BOGOR REGENCY

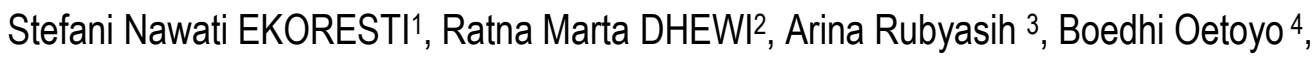 \\ Dem Vi Sara ${ }^{5}$ \\ Program Studi Pendidikan Guru Pendidikan Anak Usia Dini (PG PAUD), Fakultas \\ Keguruan dan IImu Pendidikan, Universitas Terbuka, Indonesia ${ }^{1}$ \\ Email: snawati@ecampus.ut.ac.id
}

\begin{abstract}
Taman Sari Sub-District, Bogor Regency has the potential for fertile soil. But these lands have not been tilled properly. Narrow housing conditions, especially for poor people, do not allow residents to plant crops. Causing the lack of consumption of vegetables; which causes residents become easily sick. In addition, there is also a lot of plastic waste, especially bottled drinking water and other things that come from tourists and fishermen who have not been processed. This condition gave rise to the idea to provide life skills training in making vertical gardens, hydroponic plants and waste management. Besides the need for makeup and haircutting skills also needed especially for orphans fostered by Yasayan Usawatun Hasanah. Community Service Activities (PkM) aims to foster community awareness of the cleanliness of the environment and empower citizens to be more creative and entrepreneurial. Therefore, in addition to the types of activities requested by the residents, UPBJJ-UT Bogor will also teach about identifying the economic value of the work done in the form of determining the cost of goods sold / production. This activity was attended by 50 orphans and it ran smoothly and successfully. Now orphans already have life skills that hope can lift their economy.
\end{abstract}

Keywords: orphans, life skills and empowerment 


\section{PENDAHULUAN}

Kota Bogor sebagai salah satu kota kuliner dengan tujuan wisata yang berlimpah ternyata memiliki sisi yang cukup memprihatinkan. Berdasarkan data Dinas Kependudukan dan Catatan Sipil yang dilaporkan dalam Tribunnews.com, jumlah angka kemiskinan di Kota Bogor tercatat ada sebanyak 71.314 Kepala Keluarga (KK) dari jumlah 307.730 KK pada tahun 2017. Untuk mengatasi hal tersebut Pemerintah Kota Bogor telah membentuk Tim Koordinasi Penanggulangan Kemiskinan (TKPK). Yang tugasnya melakukan pemberdayaan masyarakat, memberikan bantuan sosial dan peningkatan kesejahteraan yang kemudian dibagi menjadi tiga kelompok untuk dilakukannya sidang kelompok.

Kemiskinan yang masih tergolong besar, juga diakibatkan akumulasi ketidakberdayaan masyarakat dalam menghadapi hidup karena lemahnya kecakapan hidup (life skills) (Ramdhani dan Sumardjo, 2006). Penelitian Slamet (2003) membuktikan bahwa penyiapan sumber daya manusia untuk menanggulangi kemiskinan dapat dilakukan melalui pendidikan kecakapan hidup. Kecakapan hidup bukan hanya memiliki keterampilan tertentu, namun harus memiliki kemampuan dasar pendukungnya secara fungsional meliputi membaca, menghitung, merumuskan, dan memecahkan masalah, mengelola sumber daya, bekerja dalam tim, dan mempergunakan teknologi (Brolin, 1989; Depdiknas, 2002).

Sejalan dengan hal tersebut, Undang-Undang RI nomor 20 tahun 2003 tentang sistem pendidikan nasional pada pasal 26 ayat 3 juga menyebutkan pendidikan kecakapan hidup (life skills) sebagai salah satu pendidikan non formal yang ditujukan untuk mengembangkan kemampuan peserta didik. Pendidikan kecakapan hidup yang dimaksud adalah pendidikan yang memberikan kecakapan personal, kecakapan sosial, kecakapan intelektual dan kecakapan vokasional untuk bekerja atau usaha mandiri.

Keterlibatan dan pemberdayaan masyarakat dalam program-program pendidikan kecakapan hidup menjadi hal yang penting untuk dilakukan. Dengan memiliki pendidikan kecakapan hidup yang memadai, masyarakat dapat membuka lapangan pekerjaan sendiri yang dapat mensejahterakan kehidupannya. Program pendidikan kecakapan hidup (life skills) dapat dikembangkan pada upaya pengentasan kemiskinan dan pemecahan masalah pengangguran, dengan pemilihan keterampilan yang akan ditawarkan kepada masyarakat didasarkan pada kebutuhan masyarakat, potensi lokal, dan kebutuhan pasar, sehingga diharapkan memberi manfaat yang terbaik bagi masyarakat. 
Pendidikan kecakapan hidup tersebut sangat dibutuhkan oleh masyarakat Kota Bogor yang memiliki lebih dari 20\% masyarakat miskin, terutama dalam hal mengurangi penggangguran, menciptakan lapangan pekerjaan dan mengurangi kesenjangan sosial. Untuk memenuhi hak terhadap pendidikan bagi kelompok orang dewasa tertentu, pendidikan masyarakat diharapkan mampu berperan untuk mendorong tumbuhnya masyarakat belajar sepanjang hayat melalui program pendidikan kecakapan hidup dan kewirausahaan. Urgensi pendidikan kecakapan hidup ini sangat dibutuhkan khususnya di Kecamatan Taman Sari Kabupaten Bogor yang letaknya tidak jauh dari Kota Bogor yang merupakan domisili UPBJJ-UT Bogor. Disana terdapat lebih dari 200an orang pemudapemudi putus sekolah yang juga merupakan anak-anak yatim yang memerlukan bimbingan untuk mengembangkan kreatifitas demi menopang ekonomi keluarga; pendidikan kecakapan hidup inilah yang akan menjadi bekal bagi mereka kedepannya

Berdasarkan hasil survey pendahuluan bersama dengan mitra Pusat Kegiatan Masyarakat (PKBM) yang berupa Yayasan Uswatun Hasanah; yang salah satu pemprakarsanya adalah alumni UT PAUD tahun 2013; yang bergerak pada bidang pembinaan anak-anak yatim dan PAUD; di daerah Kecamatan Taman Sari Kabupaten Bogor terdapat sekitar 200an orang pemuda-pemudi yang putus sekolah \& yatim dikarenakan ketiadaan biaya. Pemuda-pemudi tersebut masih tergolong dalam usia produktif yang dapat ditingkatkan dan diasah kreatifitasnya dalam upaya menciptakan lapangan kerja di desanya; diharapkan hal ini dapat menyambung kelangsungan belajar formal mereka dikemudian hari.

Kecamatan Taman Sari Kabupaten Bogor memiliki potensi alam tanah yang subur. Namun tanah-tanah tersebut belum tergarap dengan baik. Kondisi rumah yang sempit terutama bagi warga kurang mampu tidak memungkinkan warga untuk bercocok tanam. Sehingga menyebabkan kurangnya konsumsi sayur mayur; yang menyebabkan warga menjadi mudah sakit. Selain itu adanya potensi sampah-sampah plastik terutama botol kemasan air minum dan lain sebagainya yang berasal dari para wisatawan yang belum diolah, memunculkan sebuah gagasan untuk memberikan kecakapan hidup pembuatan vertical garden dan tanaman hidroponik.

Selain itu hobi memancing sebagian warga sebagai pelepas penat pun dapat menimbulkan masalah lingkungan. Yaitu berupa kemasan plastik kopi dan plastik kresek yang belum termanfaatkan. Sampah plastik tersebut biasanya hanya dibuang ke tanah 
sehingga mengganggu kesuburan tanah ataupun di buang ke selokan, sehingga tersumbatnya saluran air yang menyebabkan banjir ketika turun hujan deras. Melihat kondisi tersebut remaja putri sadar akan kelestarian lingkungannya. Oleh karena itu mereka meminta pendampingan untuk mengolah sampah platik tersebut dan sisa sabun batangan yang sering terbuang percuma agar menjadi produk yang bernilai tambah.

Berdasarkan hasil wawancara dengan remaja putri di kecamatan tersebut pula, Program kecakapan hidup yang paling dibutuhkan adalah tata rias pengantin, potong rambut, mengolah sampah kemasan plastik kopi, platisk kresek dan sisa sabun batangan menjadi produk bernilai tambah. Hal ini dikarenakan mahalnya biaya untuk ke salon yang dirasakan oleh warga dan belum banyaknya perias pengantin di daerah tersebut, namun jumlah masyarakat yang menikah tergolong banyak. Sehingga UPT-UPBJJ-UT Bogor akan mengadakan pendampingan untuk melatih tata rias pengantin dan potong rambut.

Namun berdasarkan hasil need assessment lanjutan, warga belajar menghendaki pelatihan vertical garden dan hydroponic diganti dengan pengolahan sampah koran bekas dan kain perca. Karena mereka memiliki keinginan untuk lebih mengembangkan kretatifitasnya dalam memanfaatkan barang bekas menjadi barang bernilai ekonomis tinggi. Oleh karena itu UPBJJ-UT Bogor melengkapinya dengan mengajarkan mengenai identifikasi nilai ekonomis dari hasil kerja yang telah dilakukan berupa penentuan harga pokok penjualan/produksi. Program vertical garden dan hydroponic tetap dilatihkan kepada warga yatim laki-laki, mengingat pentingnya konsumsi sayur mayor terutama dari hasil panen sendiri yang non peptisida. Harapannya mereka kemudian juga dapat berbagi kecakapan yang telah didapatkan dari program PkM ini kepada pemuda-pemudi lain di daerah lain. Dengan demikian PkM ini menjadi investasi pendidikan nasional bagi pemenuhan hak warga Negara terhadap akses pendidikan bermutu yang benar-benar dibutuhkan, dapat dirasakan dan dilihat hasilnya. Sekaligus sebagai salah satu sumbangsih UT terutama UPT-UPBJJ UT Bogor terhadap program Pemerintah dalam upaya pengentasan kemiskinan.

\section{KAJIAN TEORI}

Penyelenggaraan Program Pendidikan Kecakapan Hidup merupakan upaya nyata untuk mendidik dan melatih warga masyarakat agar menguasai bidang-bidang keterampilan tertentu sesuai dengan kebutuhan, bakat-minat, dan peluang kerja/usaha 
mandiri yang dapat dimanfaatkan untuk bekerja baik di sektor formal maupun informal sesuai dengan peluang kerja (job opportunities) atau usaha mandiri. Pendidikan kecakapan hidup /life skills harus memiliki kemampuan dasar pendukungnya secara fungsional seperti: membaca, menulis, menghitung, merumuskan, dan memecahkan masalah, mengelola sumber daya, bekerja dalam tim, terus belajar di tempat kerja, mempergunakan teknologi (Brolin 1989, Depdiknas 2012). Program pendidikan life skills adalah pendidikan yang dapat memberikan bekal keterampilan yang praktis, terkait dengan kebutuhan pasar kerja, peluang usaha dan potensi ekonomi atau industri yang ada di masyarakat (Anwar 2004).

Menurut Diklusepa (2002) pendidikan kecakapan hidup yaitu memberikan bekal pengetahuan, keterampilan, dan kemapuan fungsional praktis serta perubahan sikap untuk bekerja dan berusaha mandiri, membuka lapangan kerja dan lapangan usaha serta memanfaatkan peluang yang dimiliki sehingga dapat meningkatkan kesejahteraannya. Misi dari program pendidikan kecakapan hidup adalah; 1) mengentaskan pengangguran dan kemiskinan di perkotaan/ pedesaan, 2) memberdayakan masyarakat perkotaan/pedesaan, 3) mengoptimalkan dayaguna dan hasilguna potensi dan peluang kerja yang ada, serta 4) meningkatkan kesejahteraan masyarakat melalui kegiatan kursus dan pelatihan sehingga memiliki bekal untuk bekerja atau usaha mandiri.

Hal yang sama diungkapkan oleh Nursasongko (2002) pendidikan keterampilan hidup adalah upaya mempersiapkan peserta didik agar dapat terampil hidup dan memanfaatkan peluang, sehingga memperoleh keterampilan yang layak, mandiri dan bermakna serta dapat mengembangkan diri dalam lingkungannya secara efektif. Adapun Slamet (2002) tujuan pendidikan kecakapan hidup terdiri atas empat komponen. Pertama, memberdayakan aset kualitas batiniyah, sikap dan perbuatan lahiriah melalui pengenalan, penghayatan, dan pengalaman nilai-nilai kehidupan sehari-hari sehingga dapat digunakan untuk menjaga kelangsungan hidup dan perkembangannya. Kedua, memberikan wawasan yang luas tentang pengembangan karir, yang dimulai dari pengenalan diri, eksplorasi karir, orientasi karir, dan penyiapan karir. Ketiga, memberikan bekal dasar dan latihan-latihan yang dilakukan secara benar mengenai nilai-nilai kehidupan sehari-hari. Keempat, mengoptimalkan pemanfaatan sumber daya.

Berdasarkan konsep life skills dapat disimpulkan bahwa life skills merupakan pendidikan kecakapan hidup yang memberikan bekal kepada peserta didik berupa 
pengetahuan, keterampilan membaca, menghitung, memecahkan masalah, mengelola sumberdaya, dan mempergunakan teknologi sehingga peserta didik mampu mengembangkan diri dan lingkungannya secara efektif, yang dapat meningkatkan kesejahteraannya.

\section{METODE PELAKSANAAN}

Bentuk kegiatan program Pendidikan Kecakapan Hidup merupakan pemberian keterampilan khusus kepada warga belajar/masyarakat yang kurang cakap/kurang terampil untuk menguasai kecakapan atau kecakapan hidup melalui pelatihan pada sebuah lembaga yang ditunjuk. Jenis pelatihan yang digunakan adalah pelatihan dengan praktek bekerja sesuai dengan kecakapan yang dipilih. Bentuk Kegiatan yang akan dilaksanakan adalah:

1. Pelatihan pembuatan koran bekas dan kain perca

2. Pelatihan tata rias wajah dan potong rambut

3. Pelatihan pengolahan sampah plastik dan sisa sabun batangan

4. Pelatihan perhitungan harga pokok produksi hasil kreatifitas warga

Berikut ini adalah objek intervensi yang dicarikan solusinya melalui kegiatan PkM ini.

Tabel 1. Objek intervensi

\begin{tabular}{|l|l|l|}
\hline \multicolumn{1}{|c|}{ Jenis Data } & \multicolumn{1}{|c|}{ Permasalahan } & \multicolumn{1}{c|}{ Rencana Mengatasi } \\
\hline Sarana Prasarana & $\begin{array}{l}\text { Sarana keterampilan yang tidak } \\
\text { ada }\end{array}$ & $\begin{array}{l}\text { Menyediakan sarana } \\
\text { keterampilan yang memadai } \\
\text { sesuai kondisi }\end{array}$ \\
\hline Tenaga Pengajar & $\begin{array}{l}\text { Tidak adanya tenaga pengajar yang } \\
\text { bisa membantu masyarakat } \\
\text { mendapatkan pengetahun tentang } \\
\text { kecakapan hidup (wirausaha) }\end{array}$ & $\begin{array}{l}\text { Menyediakan tenaga pengajar } \\
\text { yang mampu mengajarkan } \\
\text { pengetahuan kecakapan hidup } \\
\text { (wirausaha) }\end{array}$ \\
\hline $\begin{array}{l}\text { Rendahnya taraf } \\
\text { ekonomi }\end{array}$ & $\begin{array}{l}\text { Sebagian pemuda di Kecamatan } \\
\text { Taman Sari masih menganggur }\end{array}$ & $\begin{array}{l}\text { Menambah keterampilan khusus } \\
\text { dalam tata rias pengantin, potong } \\
\text { rambut, mengeolah sampah } \\
\text { plastic (bekas kopi dan kresek) } \\
\text { serta mengolah koran dan kain } \\
\text { perca yang tidak terpakai }\end{array}$ \\
\hline Masyarakat & $\begin{array}{l}\text { - Tingginya masyarakat yang putus } \\
\text { sekolah } \\
\text { - Sosiologis masyarakat yang } \\
\text { masih rendah kesadaran akan } \\
\text { pentingnya pendidikan }\end{array}$ & $\begin{array}{l}\text { Memberdayakan masyarakat } \\
\text { dengan memberikan pendidikan } \\
\text { informal untuk belajar kecakapan } \\
\text { hidup (wirausaha) }\end{array}$ \\
\hline
\end{tabular}


Kerangka berfikir intervensi berawal dari identifikasi sumber daya alam yang dimiliki dan kebutuhan softskill dan hardskill masyarakat Kec. Taman Sari. Identifikasi ini dilakukan dengan cara survey lapangan dan wawancara dengan calon warga belajar di kecamatan tersebut.

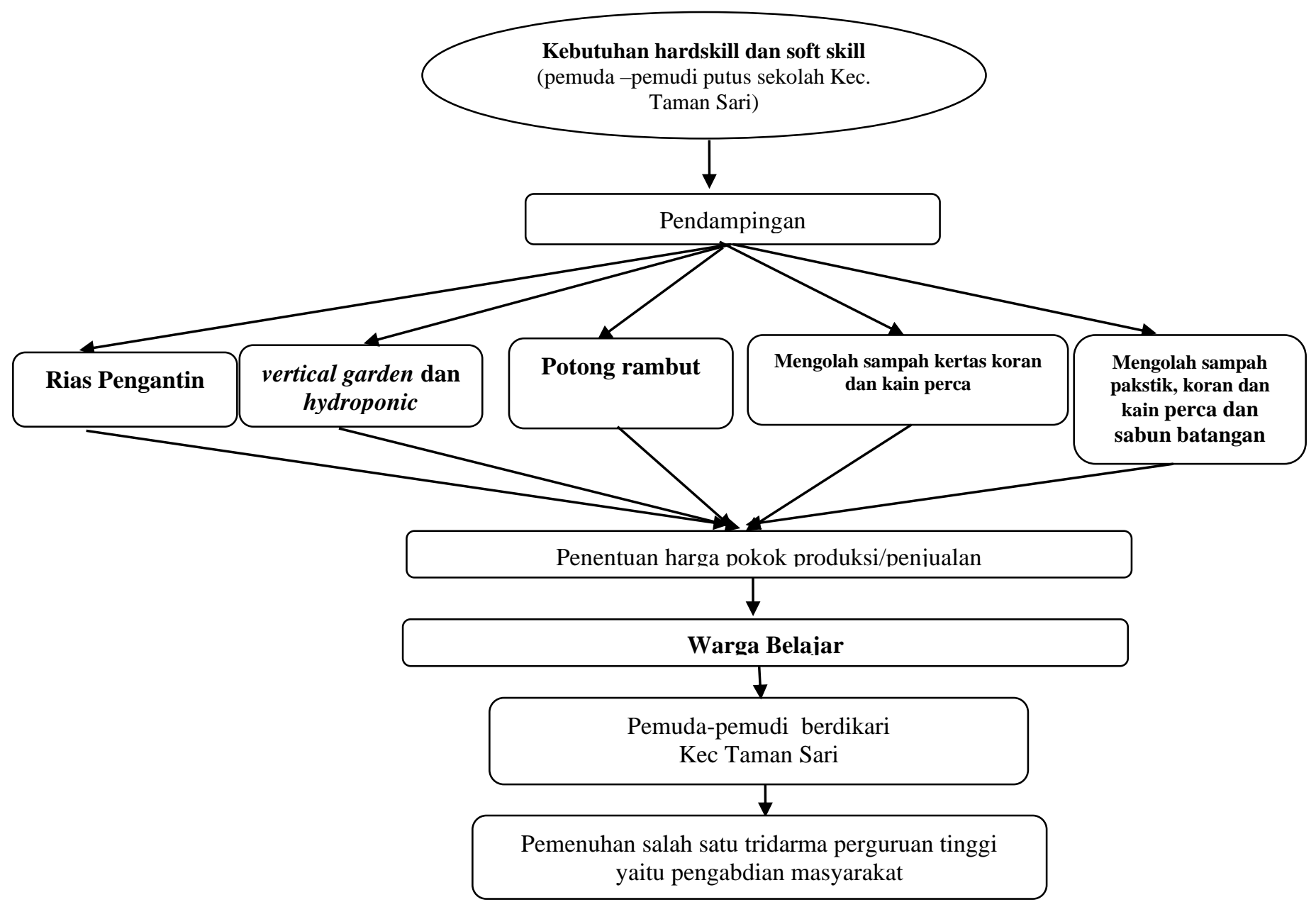

Gambar 1. Kerangka berfikir intervensi 
Secara lebih jelas berikut program-program PkM yang terdiri dari teori dan praktek:

Tabel 2. Program kerja PkM

\begin{tabular}{|c|c|c|}
\hline No & Jenis Pendidikan Kecakapan Hidup & Kegiatan \\
\hline 1 & Tata Rias & $\begin{array}{l}\text { 1. Memberi pengetahuan mengenai } \\
\text { pengelolaan keuangan untuk berbisnis rias } \\
\text { pengantin } \\
\text { 2. Memberikan pengetahuan mengenai } \\
\text { struktur kulit manusia } \\
\text { 3. Memberikan pengetahuan dan pengenalan } \\
\text { terhadap alat-alat kosmestik } \\
\text { 4. Memberikan keterampilan dan praktek } \\
\text { merias wajah: } \\
\text { a) Make up dasar wajah } \\
\text { b) Make up mata } \\
\text { c) Make up pipi } \\
\text { d) Make up bibir } \\
\text { 5. Memberian keterampilan dan praktek } \\
\text { merias rambut: } \\
\text { a) Sanggul modern } \\
\text { b) Sanggul tradisional } \\
\text { c) Jilbab pengantin modern }\end{array}$ \\
\hline 2 & Vertical garden/ hydroponic & $\begin{array}{l}\text { 1. Memberikan pengetahuan dan keterampilan } \\
\text { memanfaatkan sampah minuman botol } \\
\text { platik dan peralon } \\
\text { 2. Memberikan teknik membuat vertikal } \\
\text { garden/hydroponic } \\
\text { 3. Memberikan pengetahuan mengenai jenis } \\
\text { tanaman yang sebaiknya di budidayakan } \\
\text { untuk keperluan keluarga }\end{array}$ \\
\hline 3 & Potong rambut & $\begin{array}{l}\text { 1. Memberi pengetahuan mengenai jenis-jenis } \\
\text { rambut } \\
\text { 2. Memberi pengetahuan mengenai } \\
\text { kesesuaian antara wajah dan gaya rambut } \\
\text { 3. Memberi keterampilan teknik memotong } \\
\text { rambut anak dan dewasa } \\
\text { 4. Memberikan pengetahuan mengenai } \\
\text { peralatan yang dibutuhkan untuk potong } \\
\text { rambut }\end{array}$ \\
\hline 4 & Mengolah koran bekas dan kain perca & $\begin{array}{l}\text { 4. Memberikan keterampilan membuat tempat } \\
\text { pensil dari koran bekas } \\
\text { 5. Memberikan keterampilan membuat } \\
\text { keranjang dari koran bekas } \\
\text { 6. Memberikan keterampilan membuat bunga } \\
\text { dari kain perca }\end{array}$ \\
\hline 5 & $\begin{array}{l}\text { Mengolah sampah plastik (bekas kopi } \\
\text { dan plastik kresek) }\end{array}$ & $\begin{array}{l}\text { 2.1.1.1. Memberikan keterampilan membuat } \\
\text { tas, tempat tisu, tempat pensil, dompet, } \\
\text { taplak meja dari plastik bungkus kopi } \\
\text { 2.1.1.2. Memberikan keterampilan membuat } \\
\text { kembang dari plastik kresek bekas }\end{array}$ \\
\hline 6 & Mengolah sisa sabun batangan & 1. Memberikan keterampilan membuat \\
\hline
\end{tabular}




\begin{tabular}{|l|l|l|}
\hline No & Jenis Pendidikan Kecakapan Hidup & \multicolumn{1}{c|}{ Kegiatan } \\
\hline & & $\begin{array}{l}\text { pengharum ruangan dari sisa sabun } \\
\text { batangan }\end{array}$ \\
\hline 7 & $\begin{array}{l}\text { Identifikasi nilai ekonomi dari jasa dan } \\
\text { produk yang dihasilkan }\end{array}$ & $\begin{array}{l}\text { 1. Memberikan dasar ilmu ekonomi } \\
\text { 2. Memberikan keterampilan penentuan harga } \\
\text { pokok produksi }\end{array}$ \\
\hline
\end{tabular}

Metode yang digunakan pada pemberdayaan pemuda-pemudi putus sekolah di Kecamatan Taman Sari yaitu:

a. Penyampaian materi pembelajaran dengan menggunakan pendekatan pembelajaran partisipatif. Selanjutnya dalam proses pembelajaran akan digunakan beberapa metode pembelajaran, antara lain ceramah bervariasi, tanya jawab, demonstrasi, dan praktek langsung serta penugasan dengan mempertimbangkan pendapat dari warga belajar.

b. Praktek lapangan yaitu memberikan pengetahuan kepada warga belajar melalui pengalaman lapangan. Pelaksanaan praktik lapangan akan dilakukan dengan pola sebagai berikut:

1) Warga belajar dibagi kedalam lima kelompok-kelompok belajar. Setiap kelompok beranggotakan sepuluh orang warga belajar.

2) Materi praktik adalah pembuatan koran bekas dan kain perca, tata rias wajah dan potong rambut, pengolahan sampah plastik dan sisa sabun batangan, dan perhitungan harga pokok produksi hasil kreatifitas warga

3) Praktek akan dilakukan secara terjadwal, yaitu setiap hari Sabtu dan Minggu selama tiga bulan atau 12 kali pertemuan.

c. Monitoring yaitu suatu kegiatan pemantauan untuk mengetahui efektifitas pelaksanaan pembelajaran. Apabila ada kendala atau kelemahan, maka akan didiskusikan oleh tim pelaksana program untuk dicarikan solusinya. Kegiatan ini diadakan pada saat setelah pemberian materi maupun praktek sebanyak dua kali kegiatan

d. Evaluasi bertujuan untuk mengetahui kemajuan warga belajar dan ketercapaian tujuan pembelajaran. Evaluasi meliputi aspek kognitif (pengetahuan) dan keterampilan sesuai dengan materi yang telah diajarkan. Kegiatan ini diadakan pada saat kegiatan abdimas telah selesai untuk memastikan keberlanjutan 
penerapan hasil PkM di masyarakat. Kegiatan ini diadakan selama 2 bulan setelah kegiatan.

Sehingga total tim abdimas bertemu dengan warga adalah 14 kali yaitu pada saat pelatihan, monitoring dan evaluasi. Setelah kegiatan abdimas selesai akan dipilih kelompok terbaik sebagai kader untuk melanjutkan kegiatan pelatihan dan mengajarkannya kepada masyarakat lainnya.

\section{HASIL DAN PEMBAHASAN}

Keadaan sosial masyarakat di Kecamatan Taman Sari, Kab Bogor cukup baik, terlihat sudah banyak bangunan rumah masyarakat yang sudah seluruhnya terbuat dari bangunan yang permanen. Jalan utama yang dilalui sudah terbuat dari aspal, serta terdapat alat transportasi yang menghubungkan antar desa yang ada disekitarnya. Namun di desa tersebut jumlah warga yatim masih sangat banyak dan membutuhkan bantuan untuk pembinaan kreatifitas dan pembinaan ahlak melalui bimbingan keagamaan.

Yayasan Uswatun Hasanah adalah suatu wadah yang menyediakan informasi dan kegiatan belajar sepanjang hayat bagi warga masyarakat yang lebih berdaya. Wadah ini milik masyarakat, dikelola dari, oleh dan untuk masyarakat sejak 2006. Terdapat 30\% jumlah penduduk warga yatim di Kecamatan Taman Sari, Kab Bogor yang dibina oleh Yayasan Uswatun Hasanah berpendidikan rendah. Yayasan Uswatun Hasanah tidak meminta bayaran kepada para warga belajar, karena dana kegiatan berasal dari pemerintah maupun dana subsidi yayasan yang dimilikinya.

Yayasan Uswatun Hasanah salah satu Lembaga yang mampu memberikan layanan pendidikan unggulan dalam penerapan konsep kesatuan Iman, IImu dan Amal yang memiliki kompetensi global dan berjati diri bangsa Indonesia.

Misi

- Mengembangkan kecerdasan intelektual, spiritual dan emosional yang berbudaya dan berdaya guna.

- Membentuk generasi yang memiliki kreatifitas dan mampu berfikir logis serta unggul dan beramal soleh.

- Menghasilkan sumber daya manusia yang kreatif, inovatif, relevan dan bersikap dan bertindak serta berakhlak mulia.

- Terwujudnya sekolah yang asri, nyaman, sehat dan berbudaya lingkungan hidup. 
Sekretariat dan ruang belajar Yayasan Uswatun Hasanah berlokasi di J. Kabandungan I, Sirnagalih, Kec. Tamansari, Kab. Bogor Prov. Jawa Barat. Program yang pertama dibuka yaitu program Keaksaraan Fungsional $\{\mathrm{KF}$ ) dan program Paket B Setara SMP dan Paket $C$ setara SMA. Berbagai jenis program PNF yang diselenggarakan yaitu: Program PAUD, Program Keaksaraan Fungsional, Program Paket A setara SD, Program Paket B setara SMP, Program Paket C setara SMA Program Life Skills, Kelompok Belajar Usaha (KBU) dan Taman Bacaan Masyarakat (TBM).

Sebelum dilaksanakan PkM, tim PkM telah melakukan studi pendahuluan terkait potensi sumberdaya manusia dan sumber daya alam yang belum terberdayakan dan termanfaatkan secara maksimal. Untuk lebih memastikan terkait kebutuhan pelatihan dan jumlah peserta pelatihan tim PkM melakukan rapat internal tim dan melakukan need assessment secara mendalam bersama dengan mitra, yaitu pada tanggal 11 Agustus dan 1 September 2018.

Dari hasil need assesment tersebut di peroleh informasi bahwa potensi peserta pelatihan yang belum terberdayakan secara maksimal adalah warga yatim. Warga yatim binaan Yayasan Usawtun Hasanah seluruhnya lebih dari 100 orang. Sumber daya alam yang belum termanfaatkan lebih diarahkan terhadap pengolahan sampah. Hasil dari kegiatan need assesment warga belajar menginginkan tambahan pelatihan berupa prakarya dari bahan kertas koran dan kain perca. Karena beberapa warga belajar memiliki pekerjaan sampingan sebagai pembantu penjahit pakaian, sehingga ingin memanfaatkan kain perca agar diperoleh tambahan penghasilan. Oleh karena itu kegiatan yang diselenggarakan pada PkM ini mencakup tata rias pengantin, hydroponic, vertical garden, potong rambut, mengolah sampah plastik, koran, kain perca dan sabun batangan. Berdasarkan need assesment ini juga disepakati tanggal pelaksanaan PkM 8, 15 dan 22 September 2018. Hal ini disesuaikan dengan kesiapan dan kesanggupan warga belajar untuk menerima materi pelatihan. Tujuannya adalah untuk memastikan warga belajar dapat mengikuti rangkaian kegiatan PkM secara konsisten sampai selesai.

Peran kegiatan pengabdian pada masyarakat [PkM] yang merupakan salah satu dari tri darma perguruan tinggi sangat besar untuk memberdayakan masyarakat dalam kegiatan pendidikan kecakapan hidup dengan mengajarkan berbagai jenis pengetahuan dan keterampilan yang dibutuhkan masyarakat. Kegiatan Pengabdian masyarakat [PkM] yang dilakukan oleh Universitas Terbuka-UPBJJ Bogor kali ini bekerjasama dengan 
Yayasan Uswatun Hasanah berjalan dengan sukses. Karena kegiatan pendidikan kecakapan hidup yang diberikan dapat merubah kecakapan pribadi, kecakapan akademik dan kecakapan vokasional.

Kegiatan program PkM yang diadakan di Desa Kecamatan Taman Sari, Kab Bogor berjalan melampaui target, warga belajar yang mengikuti program sebanyak 50 orang; yang semula diprediksi hanya 25 orang. Peserta terdiri dari 45 orang wanita dan 5 orang pria, yang terbagi menjadi beberapa kelompok kegiatan sesuai dengan bidang minatnya. Berikut adalah Pelaksanaan kegiatan PkM:

1. Pada tahap awal pelaksanaan ini, diawali dengan pembagian kelompok, dilanjutkan dengan pemberian materi yang bersifat teori dan praktek. Berikut ini adalah detail pelaksanaanya:

1) Warga belajar dibagi kedalam kelompok-kelompok belajar. Dikarenakan jumlah peserta bertambah banyak maka setiap anggota kelompok yang semula direncanakan terdiri dari 8 orang, berubah menjadi lebih dari 10 orang per kelompoknya. Berikut adalah pembagian kelompok Abdimas:

a) Kelompok satu di bawah binaan Stefani NER sebanyak 10 orang

b) Kelompok dua di bawah binaan Boedhi Oetoyo sebanyak 10 orang

c) Kelompok tiga di bawah binaan Dem Vi Sara sebanyak 10 orang

d) Kelompok empat di bawah binaan Ratna Marta Dhewi sebanyak 10 orang

e) Kelompok lima dibawah binaan Arina Rubyasih sebanyak 10 orang

2. Pemberian materi yang bersifat teori. Pemberian materi yang bersifat teori ini diberikan untuk menambah rasa percaya diri para peserta PkM dalam pemasaran produk hasil karyanya kelak dan sebagai wahana sharing mengenai keagamaan untuk mempertebal iman. Materi yang bersifat teori yang disampaikan dalam Abdimas ini adalah tentang:

a) Keislaman dan kerumahtanggaan

b) Wirausaha dengan konsep ekonomi kreatif: (Penetapan harga jual produk; dan Pembukuan penerimaan dan pengeluaran uang)

c) Komunikasi bisnis

d) Pengelolaan sampah plastik, koran, kain perca dan sabun batangan

e) Pembuatan vertical garden dan hydroponic

f) Tata rias wajah dan rambut 
3. Pemberian materi yang bersifat praktek. Pemberian materi praktek, didasarkan pada sumber daya sampah yang belum termanfaatkan dan belum dikelola untuk menghasilkan pendapatan tambahan yang ada disekitar lingkungan warga yaitu berupa sampah plastik, sampah koran, sampah kain perca dan sabun batangan. Tujuannya adalah agar warga dapat memanfaatkan sampah yang dimiliki untuk kemudian diolah menjadi produk yang bernilai ekonomi lebih tinggi dari pada hanya sekedar dibuang ke keselokan atau ketanah yang dapat menimbulkan banjir dan polusi serta kerusakan tanah. Materi dan pendampingan praktek pada Abdimas ini meliputi:
a) Membuat tas dari bungkus kopi
b) Membuat dompet dari bungkus kopi
c) Membuat taplak meja dari bungkus kopi
d) Membuat bunga dari plastik kresek bekas
e) Membuat hiasan bunga dari kain perca
f) Membuat keranjang dari koran bekas
g) Membuat pengharum ruangan dari sisa sabun batangan
h) Vertical garden dan hydroponic

Selain itu warga juga mendapat pelatihan praktek berupa keterampilan:

1. Merias wajah

2. Merias rambut

3. Potong rambut

4. Membuat jilbab kreasi

Teknis pemberian materi pembelajaran baik yang bersifat teori maupun praktek adalah setiap pembina mendatangi setiap kelompok untuk memberikan materi yang menjadi kompetensinya. Sehingga setiap kelompok memperoleh materi yang sama. Kegiatan PkM ini dilaksanakan selama kurang lebih 5 jam dalam 1 kali pertemuan. Kegiatan ini dimulai dari Pk 9.00-16.00.

Berikut ini adalah jadwal pelaksanaan kegiatan.

1. Melaksanakan kegiatan pemberdayaan secara teori:

a. Pada pertemuan pertama tanggal 8 September 2018: teori mengenai Etika, kerumah-tanggaan dan keagamaan selama 1 jam. Kemudian dilanjutkan dengan teori pengelolaan sampah koran, plastik, kain perca dan sabun batangan. 
b. Pada pertemuan ke dua pada tanggal 15 September 2018: teori terkait vertical garden dan hydroponic

c. Pada pertemuan ke tiga pada tanggal 22 September 2018: teori potong rambut dan tata rias rambut dan teori tata rias wajah dan jilbab kreasi

2. Melakukan pembinaan terhadap para warga secara praktek:

a. Pada pertemuan pertama tanggal 8 September: praktek pembuatan tas, dompet dan taplak meja dari bungkus kopi, pembuatan bunga dari plastik bekas dan kain perca serta pembuatan pengharum ruangan dari sabun bekas batangan. Praktek mengenai penetapan harga jual produk, pembukuan penerimaan dan pengeluaran uang terkait hasil kreasi sampah.

b. Pada pertemuan kedua tanggal 15 September 2018: Praktek membuat pot dari peralon bekas dan botol aqua bekas, dan praktek menanam sayuran.

c. Pada pertemuan ke tiga pada tanggal 22 September 2018: praktek tatarias wajah dan jilbab kresasi. Praktek potong rambut dan merias rambut, serta praktek penetapan harga jual jasa, pembukuan penerimaan dan pengeluaran uang untuk bidang salon.

Secara lebih rinci kegiatan PkM adalah sebagai berikut.

Tabel 7. Rincian kegiatan

\begin{tabular}{|c|c|c|c|}
\hline No & $\begin{array}{c}\text { Jenis } \\
\text { Pendidikan } \\
\text { Kecakapan } \\
\text { Hidup }\end{array}$ & Kegiatan & $\begin{array}{l}\text { Nara } \\
\text { sumber }\end{array}$ \\
\hline 1 & Tata Rias & $\begin{array}{l}\text { 1. Memberi pengetahuan mengenai pengelolaan } \\
\text { keuangan untuk berbisnis rias pengantin } \\
\text { 2. Memberikan pengetahuan mengenai struktur kulit } \\
\text { manusia } \\
\text { 3. Memberikan pengetahuan dan pengenalan terhadap } \\
\text { alat-alat kosmestik } \\
\text { 4. Memberikan keterampilan dan praktek merias wajah: } \\
\text { a) Make up dasar wajah } \\
\text { b) Make up mata } \\
\text { c) Make up pipi } \\
\text { d) Make up bibir } \\
\text { 5. Memberian keterampilan dan praktek merias rambut: } \\
\text { a) Sanggul modern } \\
\text { b) Sanggul tradisional } \\
\text { c) Jilbab pengantin modern }\end{array}$ & $\begin{array}{l}\text { Ratna } \\
\text { Marta } \\
\text { Dhewi }\end{array}$ \\
\hline 2 & $\begin{array}{l}\text { Vertical gardenl } \\
\text { hydroponic }\end{array}$ & $\begin{array}{l}\text { 1. Memberikan pengetahuan dan keterampilan } \\
\text { memanfaatkan sampah minuman botol platik dan }\end{array}$ & $\begin{array}{l}\text { Dem Vi } \\
\text { Sara }\end{array}$ \\
\hline
\end{tabular}




\begin{tabular}{|c|c|c|c|}
\hline No & $\begin{array}{c}\text { Jenis } \\
\text { Pendidikan } \\
\text { Kecakapan } \\
\text { Hidup }\end{array}$ & Kegiatan & $\begin{array}{l}\text { Nara } \\
\text { sumber }\end{array}$ \\
\hline & & $\begin{array}{l}\text { peralon } \\
\text { 2. Memberikan teknik membuat vertikal } \\
\text { garden/hydroponic } \\
\text { 3. Memberikan pengetahuan mengenai jenis tanaman } \\
\text { yang sebaiknya di budidayakan untuk keperluan } \\
\text { keluarga }\end{array}$ & $\begin{array}{l}\text { dan } \\
\text { Boedhi } \\
\text { Oetoyo }\end{array}$ \\
\hline 3 & Potong rambut & $\begin{array}{l}\text { 1. Memberi pengetahuan mengenai jenis-jenis rambut } \\
\text { 2. Memberi pengetahuan mengenai kesesuaian antara } \\
\text { wajah dan gaya rambut } \\
\text { 3. Memberi keterampilan teknik memotong rambut anak } \\
\text { dan dewasa } \\
\text { 4. Memberikan pengetahuan mengenai peralatan yang } \\
\text { dibutuhkan untuk potong rambut }\end{array}$ & $\begin{array}{l}\text { Ratna } \\
\text { Marta } \\
\text { Dhewi }\end{array}$ \\
\hline 4 & $\begin{array}{l}\text { Mengolah koran } \\
\text { bekas dan kain } \\
\text { perca }\end{array}$ & $\begin{array}{l}\text { 1. Memberikan keterampilan membuat tempat pensil } \\
\text { dari koran bekas } \\
\text { 2. Memberikan keterampilan membuat keranjang dari } \\
\text { koran bekas } \\
\text { 3. Memberikan keterampilan membuat bunga dari kain } \\
\text { perca }\end{array}$ & $\begin{array}{l}\text { Stefani } \\
\text { NER }\end{array}$ \\
\hline 5 & $\begin{array}{l}\text { Mengolah } \\
\text { sampah plastik } \\
\text { (bekas kopi dan } \\
\text { plastik kresek) }\end{array}$ & $\begin{array}{l}\text { 1. Memberikan keterampilan membuat tas, tempat tisu, } \\
\text { tempat pensil, dompet, taplak meja dari plastik } \\
\text { bungkus kopi } \\
\text { 2. Memberikan keterampilan membuat kembang dari } \\
\text { plastik kresek bekas }\end{array}$ & $\begin{array}{l}\text { Arina } \\
\text { Rubyasih, }\end{array}$ \\
\hline 6 & $\begin{array}{l}\text { Mengolah sisa } \\
\text { sabun batangan }\end{array}$ & $\begin{array}{l}\text { 1. Memberikan keterampilan membuat pengharum } \\
\text { ruangan dari sisa sabun batangan }\end{array}$ & $\begin{array}{l}\text { Stefani } \\
\text { NER }\end{array}$ \\
\hline 7 & $\begin{array}{l}\text { Identifikasi nilai } \\
\text { ekonomi dari } \\
\text { jasa dan produk } \\
\text { yang dihasilkan }\end{array}$ & $\begin{array}{l}\text { 1. Memberikan dasar ilmu ekonomi } \\
\text { 2. Memberikan keterampilan penentuan harga pokok } \\
\text { produksi }\end{array}$ & $\begin{array}{l}\text { Ratna } \\
\text { Marta } \\
\text { Dhewi }\end{array}$ \\
\hline
\end{tabular}


Berikut adalah foto-foto kegiatan PkM:
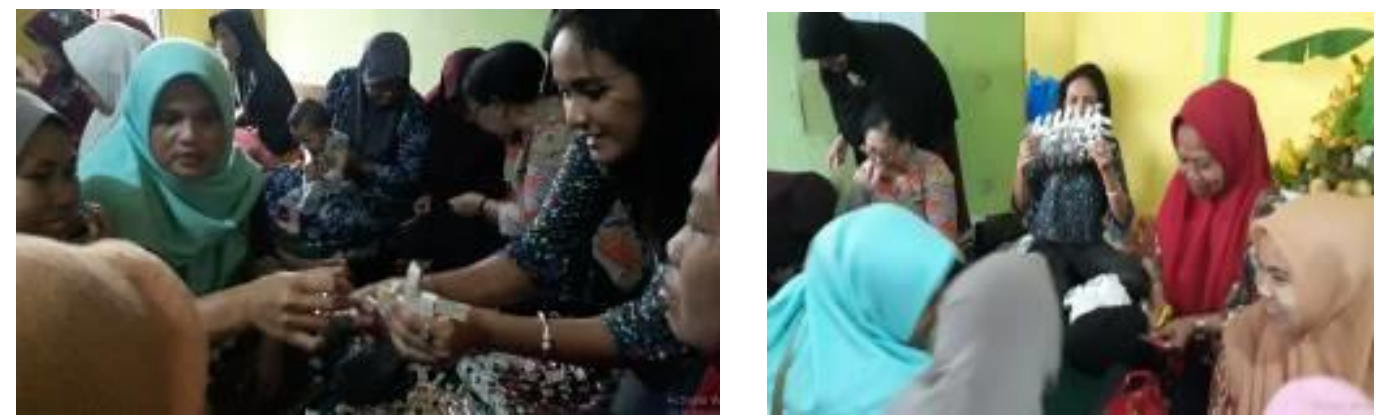

Foto kegiatan praktek1. Kegiatan praktek kreasi plastik bungkus kopi
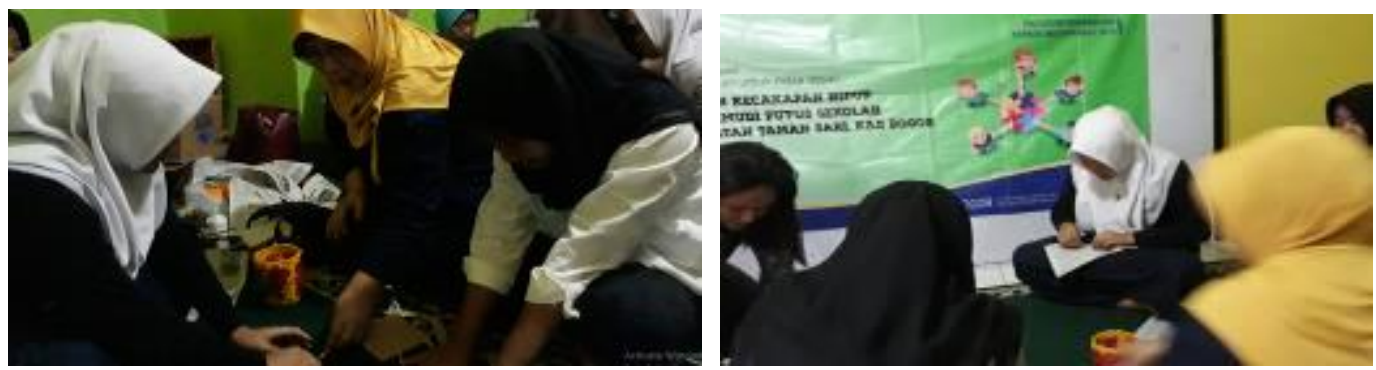

Foto kegiatan praktek 2. Membuat keranjang dari koran bekas
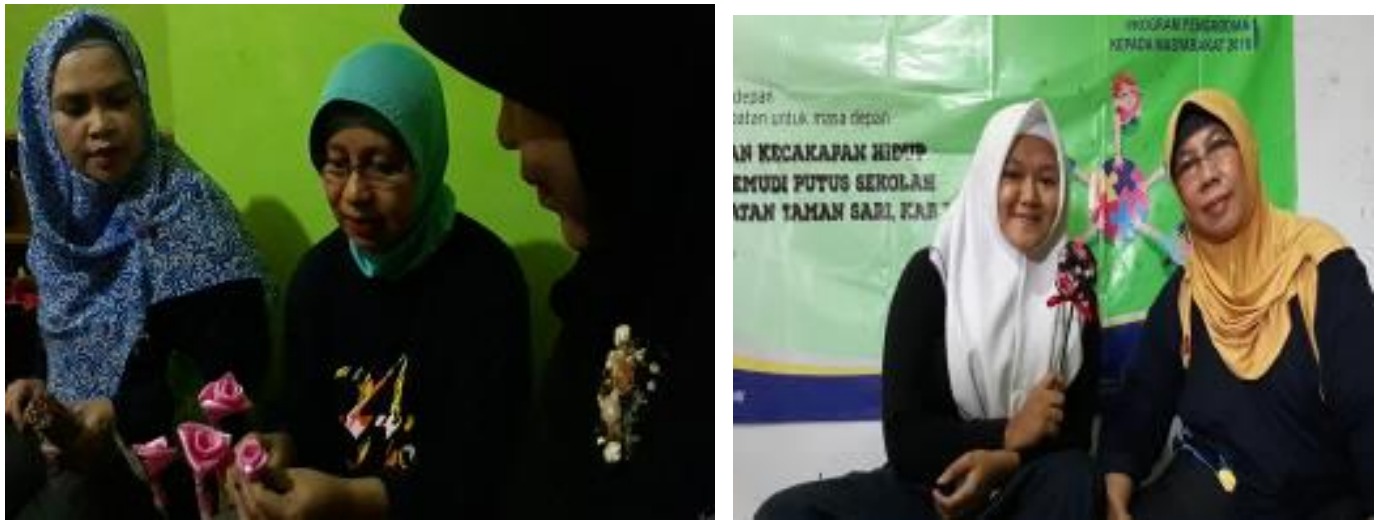

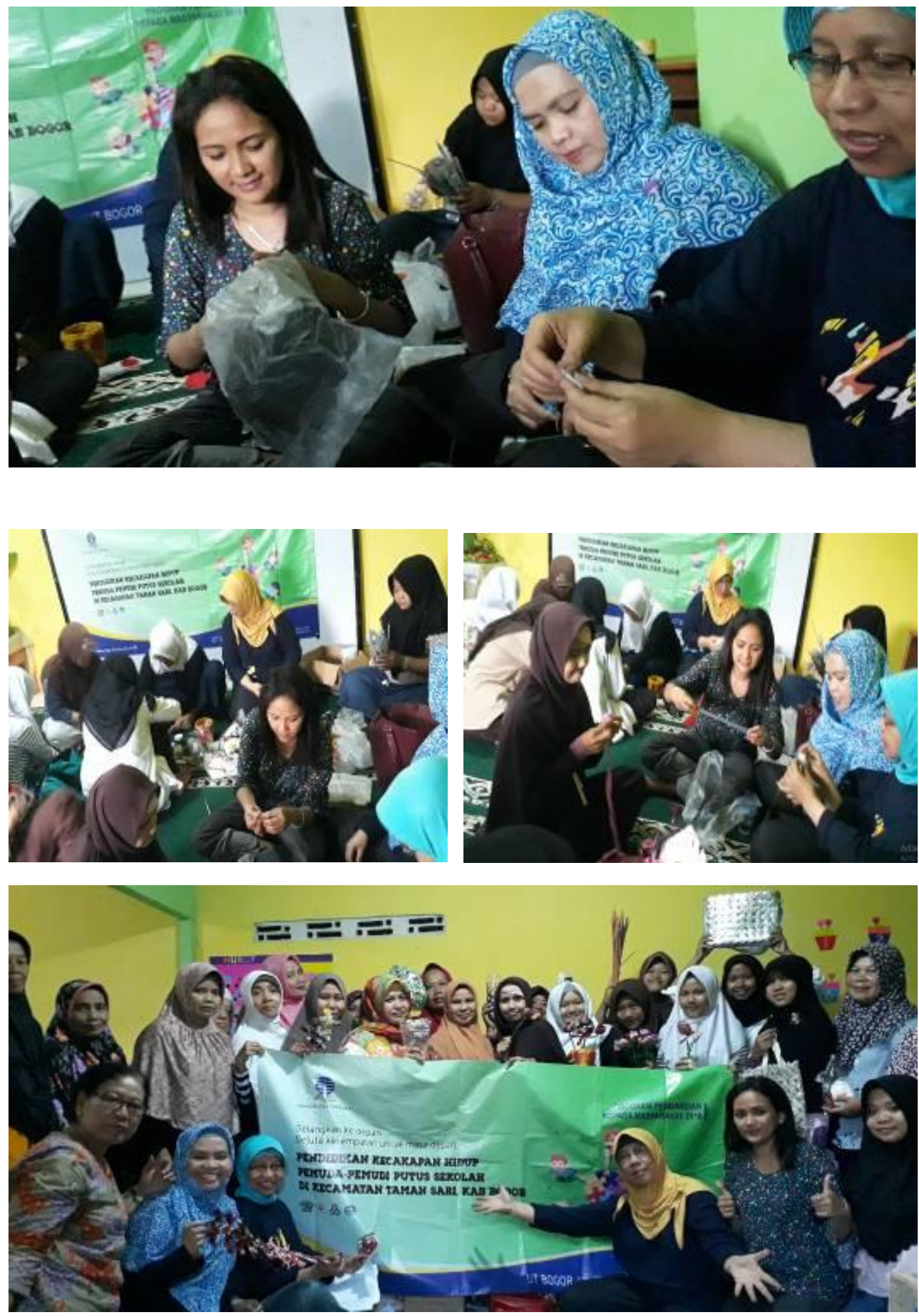


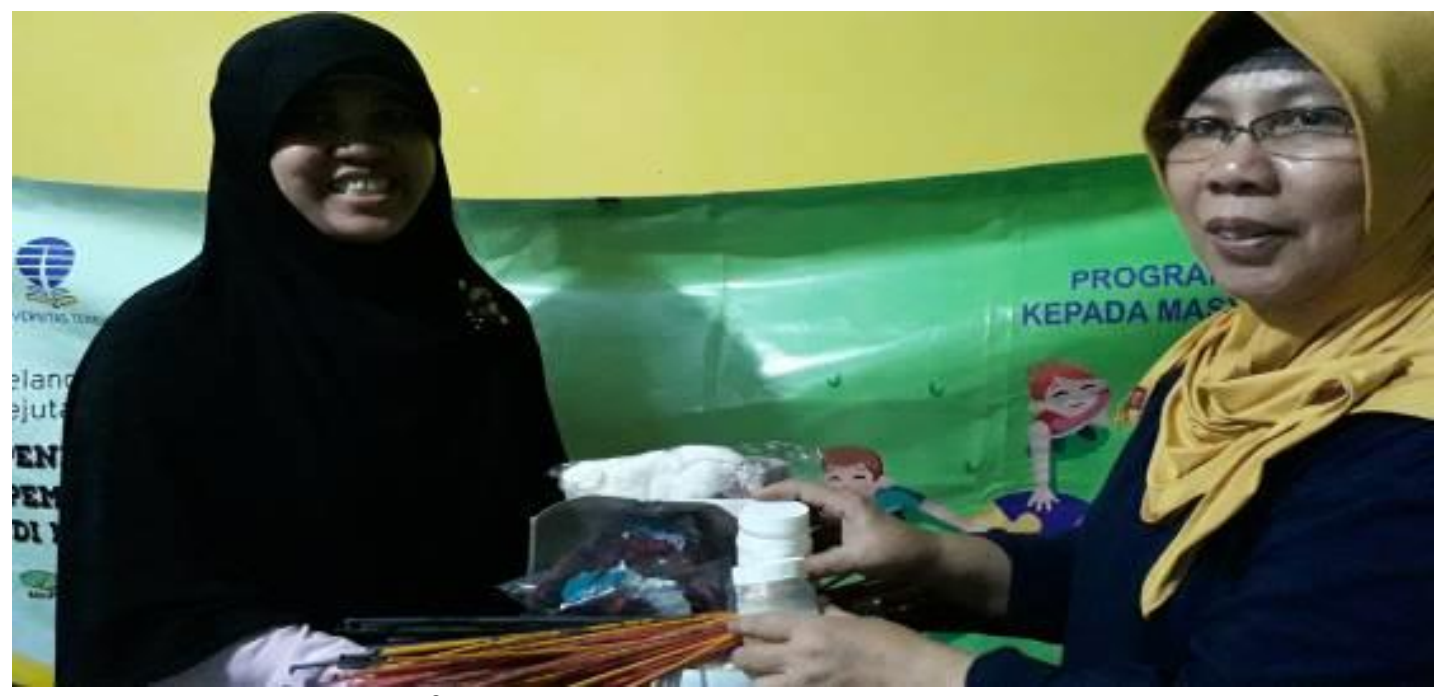

Foto kegiatan praktek 3. Membuat bunga dari kain perca dan plastik kresek serta pengharum ruangan dari sabun batangan bekas
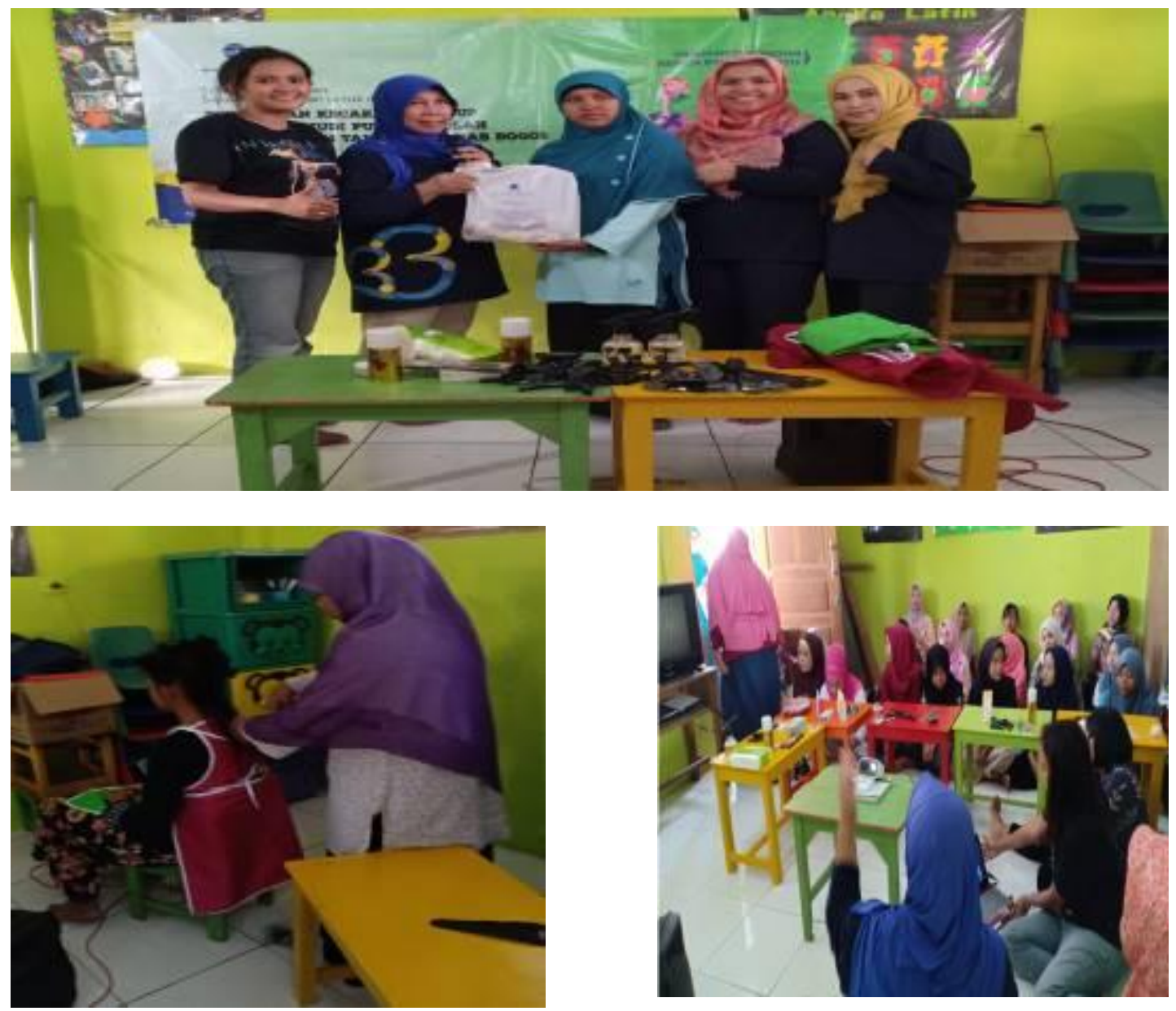

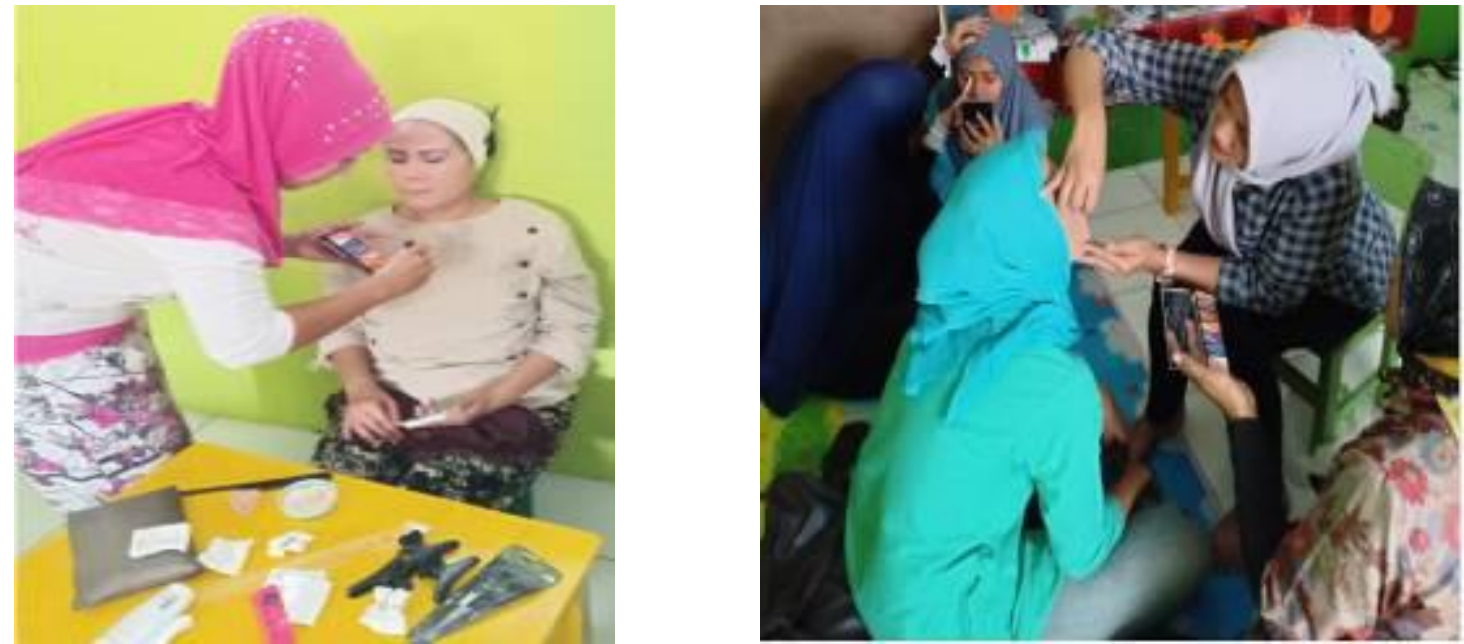

Foto kegiatan praktek 4. Tata rias wajah dan rambut
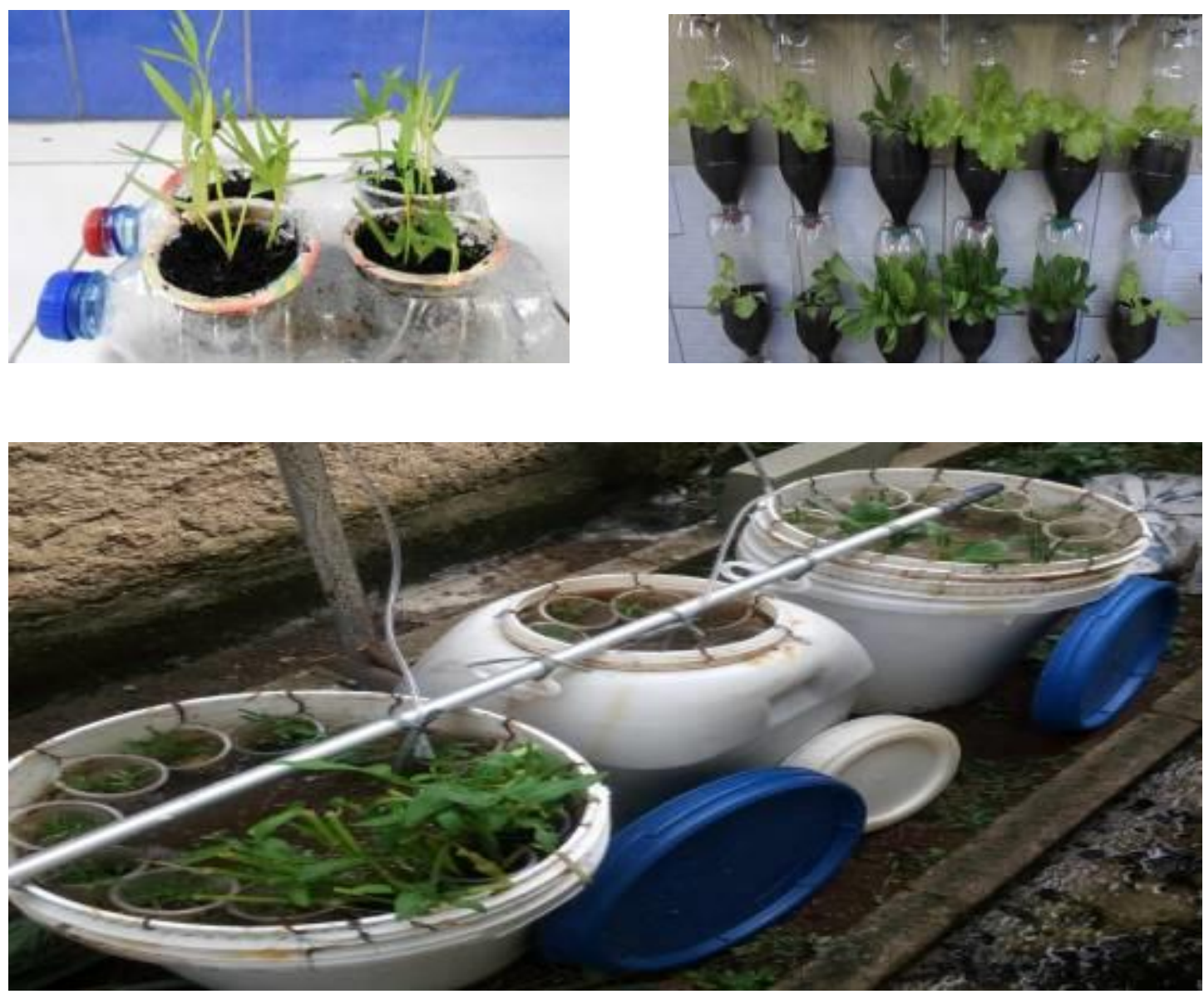

Foto kegiatan praktek 5. Vertical garden dan hydroponic 
Evaluasi dilakukan sebanyak dua kali, yaitu setelah selesai pembelajaran; teori dan pembelajaran praktik. Evaluasi setelah selesai pembelajaran teori bertujuan untuk mengukur tingkat pengetahuan warga belajar. Sedangkan evaluasi terhadap proses dan hasil praktik bertujuan untuk mengukur aspek keterampilan yang dicapai oleh warga belajar. Baik evaluasi penguasaan teori maupun evaluasi keterampilan dilakukan oleh instruktur.

Dalam pelaksanaannya setiap peserta abdimas atau warga belajar tersebut memperoleh secara keseluruhan materi dari Abdimas yang telah diprogramkan. Keberhasilan program pendidikan kecakapan hidup, mengggunakan indikator sebagai berikut:

1. Capaian hasil belajar warga belajar dapat dikatakan berhasil, karena warga belajar dapat mencapai kompetensi yang diharapkan minimal 90\%. Kompetensi yang dimaksud sesuai dengan tujuan khusus dari program ini.

2. Dilihat dari proses penyelenggaraan telah berhasil karena pelaksanaan kegiatan dapat terselenggara baik dan jumlah kehadiran warga belajar dalam mengikuti kegiatan melebihi target awal yang telah ditentukan dan tingkat kehadiran warga belajar untuk setiap materi abdimas adalah lebih dari $90 \%$.

3. Dilihat dari lembaga penyelenggara UPBJJ-UT Bogor, dikatakan berhasil karena seluruh rangkaian kegiatan mulai dari tahap persiapan sampai dengan pelaporan dapat diselesaikan dengan baik.

Dari 50 orang warga belajar, $90 \%$ dari jumlah warga belajar dapat menyelesaikan kegiatan pembelajaran. Setelah menyelesaikan kegiatan pembelajaran, warga belajar memiliki kompetensi sebagai berikut:

1. Mampu mendeskripsikan dan mempraktekan keterampilan pembuatan kerajinan tangan berbahan baku sampah plastik, koran, kain perca dan sabun batangan, vertical garden, hydroponic dan tatarias wajah serta tata rias rambut.

2. Mampu menentukan harga pokok produk yang telah dihasilkan

3. Mampu memasarkan produk kerajinannya

Kegiatan yang dilakukan setelah selesai abdimas ini sebagai tindak lanjutnya, tim abdimas dan warga belajar melakukan kegiatan sebagai berikut:

1. Membuka usaha rias pengantin, dan kerajinan tangan dilakukan oleh warga belajar PKBM 
2. Mendukung keberlanjutan kerjasama antara masyarakat dengan pangsa pasar, agar keberlanjutan produksi dapat berlangsung secara terus menerus.

Pendampingan dilakukan sejak kegiatan mulai berjalan sampai dengan melakukan pemantauan dan memberikan pembinaan dilakukan sejak awal sebelum program dilakukan secara berkelanjutan sampai berakhirnya program. Dengan langkah-langkah sebagai berikut:

1. Melakukan analisis terhadap kondisi masyarakat di daerah sasaran.

2. Melakukan penentuan sasaran Warga Belajar, dengan melibatkan aparat pemerintah setempat.

3. Proses Kegiatan yang meliputi pelatihan, pelaksanaan, dan pemasaran.

4. Tindak lanjut kegiatan dilakukan setelah pelaksanaan program berakhir. Bertujuan untuk terus membangun komunikasi antara warga belajar, Universitas terbuka UPBJJ Bogor dan mitra kerja. Serta memantau kegiatan pendidikan kecakapan hidup yang dilakukan warga belajar, jika ada permasalahan yang dihadapi dalam Pelaksanaan produksi, maka akan ada dicarikan pemecahan masalah yang baik.

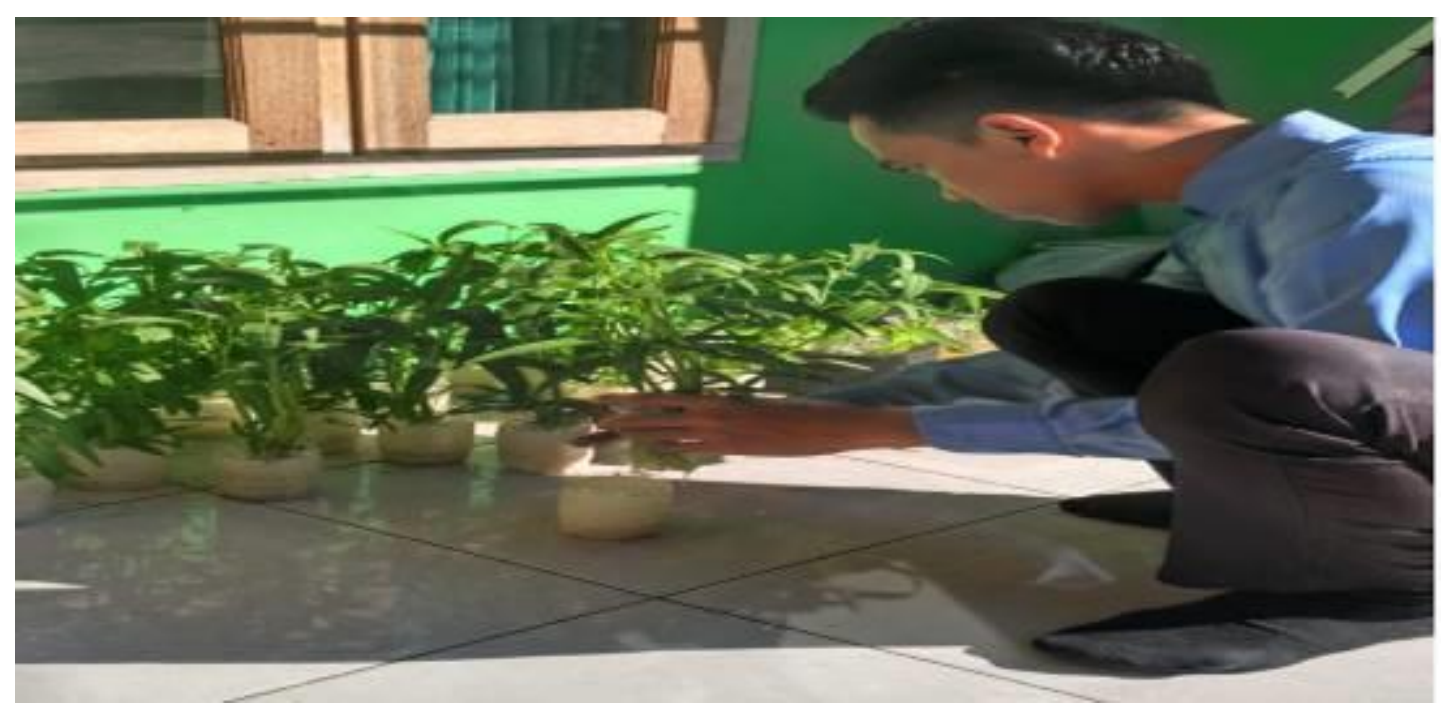

Foto kegiatan monev kegiatan hydroponic 


\section{KESIMPULAN}

Kesimpulan dari kegiatan Abdimas ini adalah:

1. Hasil dari PkM ini terus dilanjutkan oleh warga yatim binaan Yayasan Uswatun Hasanah secara mandiri setiap hari Sabtu usai pelaksanaan pengajian; mengadakan kegiatan untuk membuat produk-produk kreatif yang memiliki nilai jual. Sehingga warga yatim sudah lebih mandiri secara ekonomi. Warga yatim diharapkan dapat terus menerus berkreasi memiliki toko yang dikelola secara bersama dalam hal pemasaran produk kreatifnya

2. Tujuan dari Abdimas UPBJJ-UT Bogor adalah membantu menciptakan ketentraman, dan kenyamanan dalam kehidupan bermasyarakat. Abdimas ini sudah dapat dikatakan berhasil dalam membantu menciptakan ketentraman, dan kenyamanan dalam kehidupan bermasyarakat karena warga yatim ini sudah memiliki kegiatan positif yang dilakukan setiap Sabtu atau Minggu untuk mengupayakan mengolah SDA yang dimiliki untuk mengubahnya menjadi bahan jadi dan menjualnya dengan nilai ekonomis yang lebih tinggi dari pada menjualnya dalam bentuk bahan mentah yang kurang menguntungkan. 


\section{DAFTAR PUSTAKA}

Anwar. 2004. Pendidikan Kecakapan Hidup. Bandung: Alfabeta.

Brolin, D.E. 1989. Life Centered Career Education: A Competency Based Approach. Reston, VA: The Council for Exceptional Children.

[Depdiknas] Departemen Pendidikan Nasional. 2002. Pendidikan Berorientasi Kecakapan Hidup (Life Skill) Melalui Pendekatan Broad-Besed Education (Draft). Jakarta: Departemen Pendidikan Nasional. Pendidikan NonFormal. Jakarta: Direktorat Jendral PLS dan Pemuda Depdiknas

Diklusepa. 2002. Pedoman Umum Pelaksanaan Program Pendidikan Berorientasi Keterampilan Hidup. Jakarta: Diklusepa

[Depdiknas] Departemen Pendidikan Nasional. 2004. Pedoman Penyelenggaraan Program Kecakapan Hidup (Life Skills) Pendidikan Non formal. Jakarta: Direktorat Jendral PLS dan Pemuda Depdiknas

Nursasongko R. 2002. Mimbar Pendidikan. Bandung: UPI Press.

Ramdhani A, Sumardjo. 2006. Faktor-Faktor yang Berhubungan dengan Proses Belajar dan Tingkat Kecakapan Hidup Remaja (Kasus Pengrajin Sandal Desa Cikaret Kecamatan Bogor Selatan). Jurnal Penyuluhan. Volume 2: halaman 115-124

Slamet, Margono, 2003. Membentuk Pola Perilaku Manusia Pembangunan. Penyunting Ida Yustina dan Adjat Sudrajat. Bogor: IPB Press.

Tribun News. Ribu Keluarga Di Kota Bogor Hidup Miskin Begini Cara Pemkot Mengatasinya. Diambil 19 Februari 2018 dari http://bogor.tribunnews.com/2017/10/01/71-ribu-keluarga-di-kota-bogor-hidupmiskin-begini-cara-pemkot-mengatasinya. 